\title{
Purification of histidine-tagged nucleocapsid protein of Nipah virus using immobilized metal affinity chromatography
}

\begin{abstract}
Nucleocapsid $(\mathrm{N})$ protein of Nipah virus $(\mathrm{NiV})$ is a potential serological marker used in the diagnosis of $\mathrm{NiV}$ infections. In this study, a rapid and efficient purification system, HisTrapTM 6 Fast Flowpacked bed column was applied to purify recombinant histidinetagged $\mathrm{N}$ protein of $\mathrm{NiV}$ from clarified feedstock. The optimizations of binding and elution conditions of $\mathrm{N}$ protein of $\mathrm{NiV}$ onto and from Nickel SepharoseTM 6 Fast Flow were investigated. The optimal binding was achieved at $\mathrm{pH} 7.5$, superficial velocity of 1.25 $\mathrm{cm} / \mathrm{min}$. The bound $\mathrm{N}$ protein was successfully recovered by a stepwise elution with different concentration of imidazole $(50,150,300$ and $500 \mathrm{mM})$. The $\mathrm{N}$ protein of $\mathrm{NiV}$ was captured and eluted from an inlet $\mathrm{N}$ protein concentration of $0.4 \mathrm{mg} / \mathrm{ml}$ in a scale-up immobilizedmetal affinity chromatography (IMAC) packed bed column of Nickel SepharoseTM 6 Fast Flow with the optimized condition obtained from the method scouting. The purification of histidine-tagged $\mathrm{N}$ protein using IMAC packed bed column has resulted a $68.3 \%$ yield and a purification factor of 7.94 .
\end{abstract}

Keyword: Nucleocapsid protein; Nipah virus; Immobilized metal affinity chromatography; Escherichia coli 